« Transcendental vs. Comparative Approaches to Justice : A Reappraisal of Sen's Dichotomy »

Octobre 2012

\author{
$\underline{\text { Auteurs }}$ \\ Ragip Ege, Herrade Igersheim, Charlotte Le Chapelain \\ Document de Travail n²012 - 15
}

Faculté des sciences économiques et de gestion Pôle européen de gestion et d'économie (PEGE) 61 avenue de la Forêt Noire F-67085 Strasbourg Cedex

Secétariat du BETA Géraldine Manderscheidt Tél. : (33) 0368852069 Fax : (33) 0368852070 g.manderscheidt@unistra.fr www.beta-umr7522.fr 


\title{
Transcendental vs Comparative Approaches to Justice: A Reappraisal of Sen's Dichotomy
}

\author{
Ragip Ege (BETA, Université de Strasbourg - ege@unistra.fr) \\ Herrade Igersheim (CNRS, BETA, Université de Strasbourg - igersheim@unistra.fr) \\ Charlotte Le Chapelain (CLHDPP, BETA, Université Lyon 3 - lechapelain@unistra.fr)
}

\begin{abstract}
In The Idea of Justice, Sen describes two competing approaches to theorizing about justice: "transcendental institutionalism," in which he includes Rawls, and "realization-focused comparison," in which he includes Condorcet and himself. This paper questions the robustness of his dichotomy through an examination of the works of Condorcet, Rawls, and Sen himself. We show that none belongs exclusively to either tradition. Further, we claim that an appeal to the concept of metaranking, developed by Sen in the 1970s, enables us to overcome the distinction between the transcendental and the comparative traditions and in the last instance to reconcile the two approaches.
\end{abstract}

\section{Introduction}

In The Idea of Justice (2009), Sen sets out what he considers to be two competing traditions in thinking about justice: "transcendental institutionalism," and "realization-focused comparison." The transcendental institutionalist approach aims to identify an ideal of justice and then, on that basis, to define the nature of just institutions. Sen claims, with some justification, that this approach is currently dominant within political philosophy. In contrast, the approach of "realization-focused comparison" does not place the definition of just basic institutions at the heart of analysis; rather, it aims to give practical tools to discriminate between real situations, focusing on the outcomes realized by actual social institutions, and not attempting to provide a definition of what a just institution would be. According to Sen, the transcendental institutionalist approach - which is based on the social contract model fails to reach the fundamental goal of any theory of justice: namely, the creation of tools which allow us to achieve greater social justice in the real world. Sen's criticism of the socalled transcendental tradition (henceforth TT) turns on his argument that possessing an overall conception of justice is neither necessary nor sufficient in order to formulate comparative judgments regarding social justice. Hence he advocates a "paradigm shift in theorizing about justice" (Valentini 2011) in favor of the comparative tradition (henceforth

\footnotetext{
${ }^{1}$ On these issues, see also Sen 2006 and 2012.
} 
CT). Social choice theory, which is concerned with the ranking of social states, then emerges as a better framework for reflection on social justice issues than the social contract model. Sen writes that Hobbes, Locke, Rousseau, Kant, and more recently Rawls, all belong to this contractarian or transcendental tradition; while, Smith, Condorcet, Wollstonecraft, Bentham, Marx, J. S. Mill, Arrow, and his own thoughts as set out in The Idea of Justice, correspond to the comparative, "alternative" tradition (2009, p. xvi).

The aim of our paper is to question whether Sen's dichotomy between transcendental and comparative approaches is really as robust as he claims, via an examination of the works of three great authors: Rawls, Condorcet - and Sen himself. Our aim in this article is not to pose general questions regarding the distinction between the two traditions -- in the manner, for instance, in which Kandil (2010), Robeyns (2012), and (though to a lesser extent) Gamel (2010) have claimed, contrary to Sen, that the traditions are in general complementary -- but rather to study them in a more specific manner, through reference to the work of Rawls, Condorcet, and Sen. In our opinion, none of these great thinkers exclusively belongs to just one of the two camps represented by TT or CT. This is because all of them place special emphasis in their thought on the idea of public debate. Sen himself stresses this commonality, writing that "despite the differences between the two traditions of the Enlightenment - the contractarian and the comparative - there are many points of similarity as well. The common features include reliance on reasoning and the invoking of the demands of public discussion" (Sen 2009, p. xvii). But the appeal to the notion of public discussion carries with it certain commitments and has consequences that cannot be ignored. For these three authors, public discussion both stems from and gives rise to the Kantian "reasonable" - albeit that they refer to this notion in different ways: "collective reason" for Condorcet, "public reason" for Rawls, and the "moral code of behavior" or "reasoned values" for Sen. In this paper we discuss the role of public dialogue and the notion of the "reasonable," and argue that the concept of metaranking - the ordering of orderings of preferences - provides a way of bridging the gap between TT and CT. Crucially, we also note that the concept of metaranking was developed by Sen himself in the 1970s.

The paper is organized as follows. In the first section we examine Rawls's thought and its evolution from A Theory of Justice (1971) to Political Liberalism (1993). While we accept Sen's claim that the early Rawls belongs to a large extent to TT, the later Rawls is closer to CT. In the second section we discuss Sen's assertion that Condorcet can be seen as a representative of CT. Although Condorcet is a well-known forerunner of modern social choice theory, reflection on his famous voting paradox does not warrant associating him solely with CT. In the third section we turn to Sen's theory itself. The analysis of Rawls and Condorcet having brought out the crucial role of the Kantian concept of the "reasonable" in the public decision-making process, we now emphasize that this appeals to the modification of individual preferences induced by public deliberation; and we note further that these 
considerations are apparent in the "early" Sen, as expressed in his "liberal paradox" and the related concept of metaranking. Finally, we claim that by appeal to this concept of metaranking - a concept which resonates with many passages in The Idea of Justice - we may overcome the dichotomy between TT and CT and so reconcile the traditions.

\section{Rawls: from transcendental to comparative}

Although Sen considers Rawls's work to be the twentieth century's most important theoretical investigation of justice, his own The Idea of Justice represents an effort to build an alternative theory which is more realistic, concrete, and also less ambitious, than the Rawlsian one. In section 1.1, we examine to what extent Sen's reading is sensitive to the early Rawls's philosophical concerns; we then explore in section 1.2 the evolution of Rawls's thought from A Theory of Justice (1971) to Political Liberalism (1993).

\subsection{The early Rawls as a representative of the transcendental tradition}

Sen describes Rawls as the last great representative of the contractarian and transcendental tradition; in fact, Rawls himself declares that the aim of his theory of justice as fairness is "to generalize and carry to a higher order of abstraction the traditional theory of the social contract as represented by Locke, Rousseau and Kant" (Rawls 1971, p. xviii). Sen observes, however, that "The exercise of fairness through the approach of social contract is geared, in the Rawlsian case, to identifying only the 'just institutions' [...]. In the Rawlsian system of justice as fairness, direct attention is bestowed almost exclusively on 'just institutions' rather than focusing on 'just societies' that may try to rely on both effective institutions and on actual behavioral features" (Sen 2009, p. 67). In contrast to this, Sen tells us that his own concern is not to speculate "on what a perfectly just society [...] would look like" (ibid., p. 106). In his evaluation of the early Rawlsian theoretical project, and of the contractarian approach to justice as considered more generally, Sen makes use of two key concepts which stand in need of closer inspection: that of a "perfect" principle of justice, and that of a "transcendental" theory of justice.

Our first question, then, is whether Sen is right to consider the ultimate aim of social contract theory as being to define "perfect" principles of justice, which can act as the foundations of "perfect" institutions, with the aim of reaching a "perfectly just" society. Is it justifiable to see the contractarian adventure merely as a naïve quest for perfection? On closer examination things turn out to be much more complex. First, one must underline the insurmountable difficulties with which the contractarian enterprise is faced (difficulties recognized by the contractarians themselves). In Rousseau's formulation, social contract theory desires "to know accurately a state which no longer exists, which perhaps never did exist, which probably never will exist, and about which it is nevertheless necessary to have 
exact Notions in order accurately to judge of our present state" (Rousseau 1755, p. 125). The state in question here is the "state of Nature." By definition, such a state cannot be empirically observed; but we may try to approach it through subtle efforts of the imagination, adopting necessarily unrealistic and heroic hypotheses such as the "original position," "veil of ignorance," the "categorical imperative," etc. For this reason Rousseau is careful to specify that "the Inquiries that may be pursued regarding this Subject ought not be taken for historical truths, but only for hypothetical and conditional reasonings; better suited to elucidate the Nature of things than to show their genuine origin" (Rousseau 1755, p. 132).

Rawls's position concerning his own theory of justice is similar to Rousseau's. He expressly recalls that the "original position" posited by his theory "is not, of course, thought of as an actual historical state of affairs [...]. It is understood as a purely hypothetical situation characterized so as to lead to a certain conception of justice" (Rawls 1971, p. 11). The fiction of the "state of Nature" reveals, according to Rousseau, that the individuals who deploy in such a state cannot be imagined as subordinated to relations of domination and bondage; they cannot be imagined except as physically independent of one another. Consequently, such "natural" creatures are supposed to agree to leave the state of Nature only if they are assured of the protection of their independence in the new state, namely the state of culture. The contractarian approach supposes that this process of transition necessarily requires the adoption of a social contract by all (absolutely all) of the individuals who are to leave the state of Nature. The hypothesis of the social contract turns out to be a philosophical inquiry into the conditions of the possibility (in the sense of Kant) of these crucial deliberations; that is to say, the conditions of possibility of the debate that will give birth to human society - the state of culture - as such. Clearly, historically speaking, there has never been such an agreement as the "social contract." All serious contractarians recognize that the idea of a social contract is a pure fiction. Human beings, whatever the particularities of their existence in time and space, always encounter society as a reality which necessarily precedes them. As regards the individual, society represents precedence par excellence. The question then arises: What is the significance of considering a hypothesis which we know for certain never took place? The answer: Because it reveals that at the point of origin of human society we cannot but place a process of debate, discussion, and deliberation. The fiction of the social contract expresses this necessity. Consequently, the contractarian approach is in no respect a search for the perfect or ideal society; rather, it is an interrogation regarding the conditions of human society as such, where it is supposed that the latter is necessarily the product of a deliberative process.

We now turn to the second concept which plays a key role in Sen's reasoning, namely the "transcendental." Sen thinks that we do not need a transcendental theory of justice to be able to compare two social states and determine which of them is more just. This, then, brings us to the "alternative approach" which Sen calls "realization-focused comparison" (Sen 2009, 
p. 7). This comparative approach is posited as standing in radical opposition to the transcendental approach, insofar as it is "directly focused on the actual societies that would ultimately emerge." While the comparative approach contents itself with looking for a theoretical framework which allows us to frame judgments of the form "society $\mathrm{X}$ is more just than society Y," the Rawlsian contractarian approach aims to identify the principles which will us allow to frame judgments of the form "society X is perfectly just." The comparative approach claims to have set voluntary limits to its theoretical ambition, desiring not to achieve "perfect" justice but only to increase its prevalence in society. But closer analysis suggests that there is a problem with Sen's reasoning. It is only on a utilitarian approach that justice can always be increased, since utilitarianism analyzes justice in terms of utility, and sets no limits on the total amount of utility that can be attained (that is to say: the sum total of utility can always be increased). But a conception of justice as susceptible to arithmetical addition is unacceptable: "the correct account of justice does have a cut-off point beyond which the idea of an increase in justice simply makes no sense" (Valentini 2011, p. 305). This "cut-off point" is precisely the point of reference according to which one may gauge improvements in our society in terms of justice (for instance, Rawls's principles of justice comprise such a reference point). On inspection, what Sen considers transcendental in the contractarian theory of justice appears to be one of the constitutive components of any theory of justice. The fact that no real society corresponds to the criteria set up in the theory cannot authorize the conclusion that the question of the conditions of a just society must be abandoned in favor of a more realistic paradigm. This conclusion amounts to renouncing any attempt to elaborate a theory of justice as such. The early Rawls chose to privilege such an elaboration of the conditions of possibility of a just society. That is the reason why Valentini (2011) proposes to substitute the term "transcendental" with "categorical," insofar as the main concepts of the early Rawlsian enterprise are essentially Kantian ones.

\subsection{The later Rawls: towards a more comparative approach}

Rawls, however, goes further than his great contractarian predecessors. With the second principle of justice set out in A Theory of Justice, he introduces the issue of inequalities between fundamentally equal citizens. Here we find the "realistic" dimension of the Rawlsian theory. In fact, the question of the inequalities - or, more precisely, the question of inequality in equality - is one of Rawls's major concerns. The reason for this lies in the fact that he never contented himself with advancing a theory which was limited to the abstract determination of the conditions of formal liberty. Real liberty requires reflection on the concrete and material inequalities in society. What is a reasonable distribution of the material conditions of the exercise of liberty in society - i.e., a reasonable arrangement for the distribution of wealth? Rawls's inclusion of "income and wealth" among the primary goods, as well as his framing of the second principle of justice (especially the difference principle), 
could be seen as an effort to respond to this question. The early Rawls even took the liberty of pushing his concern for realism so far as to suppose that partners in the original position would behave according to rational choice theory. Later he recognized the incoherence of this move:

it was an error in Theory (and a very misleading one) to describe a theory of justice as part of the theory of rational choice [...]. What I should have said is that the conception of justice as fairness uses an account of rational choice subject to reasonable conditions [...]. There is no thought of trying to derive the context of justice within a framework that uses an idea of the rational as the sole normative idea. That thought is incompatible with any kind of Kantian view. (Rawls 1985, n. 20)

The fiction of the "original position" indeed cannot but rest on the notion of "reason" as so magisterially conceptualized by Kant in his moral philosophy. But this mea culpa did not lead Rawls to abandon his aspirations towards realism. In other words, he did not abandon his inquiry into the complex mechanisms of difference in society, or of the "rational," in favor of a purely Kantian position - quite the contrary! It is precisely this point to which Sen seems to pay very little attention, and we think that this omission prevents him from noticing how close the later Rawls's position is to what he calls the comparative approach. However, we do accept that Sen recognizes the intellectual evolution in Rawls's thought - indeed, he writes that "Rawls's basic claim of the emergence of a unique set of principles of justice in the original position (discussed and defended in his A Theory of Justice) is considerably softened and qualified in his later writings" (Sen 2009, p. 58). Nevertheless, Sen tends to minimize the theoretical significance of this evolution, saying "in his later writings, Rawls makes some concessions to the recognition that 'citizens will of course differ as to which conceptions of political justice they think most reasonable"' (Sen 2009, p. 11). We believe that this evolution is far more important than this reference to "simple concessions" would allow. The question at stake concerns the nature of the articulation between two concepts: the "rational" and the "reasonable."

From the outset, Political Liberalism (1993) denounces the metaphysical character of the reasoning which governs the 1971 theory of justice. What Rawls describes as "metaphysical" is the fact that his earlier theory supposes the existence of pure reasonable actors, inspired by their "sense of justice," and subordinated to the Kantian "categorical imperatives," i.e, the principles of justice. But Rawls increasingly comes to realize that his efforts to provide space for the expression of "hypothetical imperatives" - i.e., the "rational" - in his earlier theory harbor logical incoherencies. And at the same time, the correlative problem of the plurality of the conceptions of the good becomes ever more important for him. His inquiry now focuses on the conditions for the peaceful coexistence of multiple conceptions of the good - which may even be incompatible, provided that they are 
reasonable. But how should we understand the concept of the "reasonable" in this context? How can we conceive of a form of reasonability which is not metaphysical? This question transforms the nature of the Rawlsian project: his theory is no longer a pure "moral" theory of justice, and evolves instead towards a "political” one. The later Rawls's research program is thus limited to the construction of a political theory, or, more precisely, the investigation is ever more concentrated on the conditions of possibility of a basic political structure for society which can allow individuals to develop reasonable though incompatible conceptions of the good. This is why the concept of "public reason" becomes the major concern of Political Liberalism (on this issue, see in particular Ege and Igersheim 2010). The emergence of public reason in society necessitates the existence of a democratic cultural accumulation, in the sense that, through specific historical experiences, individuals are supposed to have progressively integrated an ethic of deliberation. Hence, in the context of constitutional democracies, only individuals who have assimilated public reason and therefore acquired the qualities of citizens can ensure the coexistence of opposite conceptions of the good. In other words, the later Rawls's theoretical position can no longer lay claim to universality; its teaching is valid only within the limits of modern occidental societies, or, in Rawls's terms, within the limits of "well-ordered constitutional societ[ies]" (Rawls 1993, p. 448).

As a consequence, what Sen calls the transcendental dimension of Rawls's theory of justice is indeed carried over to Political Liberalism, but its scope is considerably restricted. Like Sen's own works, Political Liberalism is greatly attentive to the existence of different "arguments each point[ing] to a different type of impartial and non-arbitrary reason" (Sen 2009, p. 15). Political Liberalism is oriented towards providing a comparative theory of justice, but does not neglect the question of the conditions of possibility of such a theory.

This problem for Sen's dichotomy, which our discussion of Rawls's work has revealed, can perhaps be deepened through a consideration of the works of a second author: Condorcet.

\section{Condorcet: from comparative to transcendental}

Social choice theory has seen Condorcet as a forerunner ever since Guilbaud (1952), Arrow (1951), and Black (1958) rediscovered the Condorcet Paradox or Effet Condorcet, originally set out in the Essai sur l'application de l'analyse à la probabilité des décisions rendues à la pluralité des voix (1785). Arguing that social choice theory is the framework of analysis that is most representative of $\mathrm{CT}$ in theorizing about social justice, and recalling that its foundations rest on Condorcet's work, ${ }^{2}$ Sen associates Condorcet's thought with that tradition. In this section, we ask whether Condorcet's thought does indeed display features distinctive of CT - in opposition to TT - by examining the way Condorcet tackles the issue of public decisions. Modern social choice theories have retained only a small part of Condorcet's

\footnotetext{
${ }^{2}$ Sen (2009, pp. 91-92) also recalls the legacy of Borda's analysis.
} 
overall project, which is to set up the conditions that guarantee that the process of public decision-making takes its only acceptable form: the collective pursuit of the general interest. In section 2.1 we note that this conception of public decision-making - as a public dialogue devoted to collectively realizing the general interest - may appear at first sight to be close to Sen's comparative tradition. In section 2.2, however, we go on to argue that these first impressions are in fact inconsistent with Condorcet's own approach to defining the general interest, which is couched in transcendental terms.

\subsection{The vote as a collective quest for justice: Condorcet and CT}

The Essai - Condorcet's most fruitful attempt to apply probability theory to the moral and political sciences - asks the question: "under what conditions will the probability that the majority decision of an assembly or tribunal is true be high enough to justify the obligation of the rest of society to accept that decision?" (Baker 1975, p. 228). Given that this is the wider issue of interest to Condorcet, the Paradox, as - in contemporary terms - a logical and mathematical problem of preference aggregation, cannot be seen as representative of the Essai considered as a whole. As Bru and Crépel have noted (1994, p. 376), the discussion on the Paradox, however important, "represents only few pages of the Essay"; Grofman and Feld (1988, p. 569) describe Condorcet's Paradox as a "by-product" of the Essai, albeit one that has, through the influence of modern social choice theories, become the most famous part of Condorcet's reflections on public decision-making.

When dealing with the issue of public decision-making, Condorcet's problem is not the accuracy with which the social preference conforms to the multitude of individual preferences, but rather the way in which the social decision-making process is able to lead to a "true" result, that is, a result in compliance with the general interest. From this point of view, public decision-making has nothing to do with the opinion of the majority, and is not concerned with the expression of a balance of competing wills. Rather, the public decisionmaking process must be nothing less than a collective "quest for truth," and the problem of the Essai is to identify the forms and compositions of assemblies that may ensure that we can have confidence in democracy as a tool to collectively identify the general interest.

The "probability of truth" of public decisions certainly depends on the form of assemblies and on aggregation issues. However, the emergence of a "true result" also has a prior dependency on the individual decisions themselves, and more specifically, in Condorcet's words, on the "probability of truth" of each individual vote. The latter, though, turns crucially upon the enlightenment of the voters themselves: "Thus the form of an assembly which decides upon men's fate is far less important for their happiness than the enlightenment of its members; also the progress of reason will contribute more to the good of the people than the form of political constitutions" (Condorcet 1785, p. 1xx; 1994, p. 130). 
What emerges from this analysis is the most important outcome of Condorcet's reflections on public decision: the process of collective choice cannot escape arbitrariness, and thus injustice, if individual choices are not grounded on the exercise of reason. Condorcet hence stresses two fundamental prerequisites of democratic public decisions: first, the need for enlightened citizens to be involved in collective choice, and, second, the role of public debate as a way to collectively promote reason. When associating Condorcet with CT, Sen (2009, p. 94) specifically mentions the importance of these two prerequisites and evokes the strong link that unites Condorcet's reflections on the vote with his defense of a public instruction system. Condorcet's passionate advocacy of public instruction must indeed be appreciated as an integral part of his meditations on the emergence of rational public decisions. Insofar as the public instruction system is supposed to spread reason to all citizens, Condorcet considers it to be the most important institution with respect to securing the grounds for a republican regime.

Through the notion of reason, Condorcet lays emphasis on the need for the impartiality of the citizens involved in the public decision-making process. He draws a strict distinction between the reason and the will (Condorcet 1792, pp. 589-590): reason concerns the need that all citizens involved in a public decision should distance themselves from their particular will - i.e., their own personal interest - so as to give priority to the common interest. The collective exercise of reason - sometimes called "collective reason" or "common reason" appears as the central condition of the emergence of just social arrangements. Hence impartiality can be seen as a condition of the possibility of public discussion, which in its turn gives rise to the emergence of collective reason. Consequently, and contra the claims that, as a forerunner of modern social choice theory, Condorcet belongs to CT, the use he makes of the concept of collective reason actually shows that he has some transcendental concerns - and this is all the clearer given that collective reason is supposed finally to lead to a unique principle of justice which applies to all members of a society.

\subsection{From collective reason to principles of justice}

According to Condorcet, collective reason must necessarily lead to a fundamental principle of justice: just social decisions must give primacy to the preservation of the equality of the principle of natural rights. Indeed, in Condorcet's view, when citizens set aside their own interests they necessarily observe that all members of society, as human beings, share the same moral faculties: in particular, reason and sensitivity. In consequence, they must share the same fundamental rights, which are natural rights. Equality of natural rights hence appears as a fundamental principle which is justified through reflection on the moral nature of humanity. Through this sensualistic justification (see Faccarello 1990, 1992; Rieucau 1997), Condorcet affirms that respect for the equality of natural rights takes priority over every other concern, especially economic ones - although he does not consider these objectives to be antagonistic, 
in fact quite the contrary (Rieucau 1997, Le Chapelain 2010). That move from collective reason to the priority of the equality of natural rights explains why Condorcet regards laws as "consequences" and "applications" of natural rights (Condorcet 1792, p. 594-595). The reason why men join in society is precisely the preservation of these rights. The political constitutions and laws that follow from public decisions thus must naturally preserve that principle: "We want a constitution whose principles are only based on the natural rights of the man, before the social institutions" (Condorcet 1787, p. 14).

From that point of view, Condorcet's and Rawls's analyses of social justice have a profound commonality. They both move deductively from impartiality - reached through the spread of reason or following from the original position - to an agreement on a unique set of principles of justice and on the lexicographic ordering of these principles. They both set out that impartial public reasoning must necessarily lead to an agreement on a specific contract characterized here by the same priority of fundamental liberties. From that perspective, Condorcet's analysis possesses one of the central characteristics of the contractarian tradition. The general interest (i.e., the primacy of the principle of the equality of natural rights) does not have plural forms; it is unique and anterior to public dialogue since it is justified by considerations of the essential moral character of humanity. Collective decisions grounded on collective reason are not perceived by Condorcet as a way to make progress in matters of justice, but as a way to bring to light the only pre-existent social contract that could possibly exist, given the moral character of humanity. The parallel drawn by Baker (1975) between Rousseau's Contrat social and the Essai supports the idea of the contractarian nature of Condorcet's analysis. In the same vein, Grofman and Feld (1988) show the proximity between Rousseau's concept of the general will and Condorcet's general interest, and propose that Condorcet's analysis in the Essai, especially the "jury theorem," "accurately captures the basic ideas underlying Rousseau's notion of the general will" (Grofman and Feld 1988, p. 567). Consequently, contrary to Sen's claim (2009), Condorcet's thought develops away from the comparative tradition and ends up closer to the transcendental institutionalism of Rousseau and Rawls.

Indeed, what Sen considers as a main virtue of the comparative approach, the capacity to take into account the plurality of impartial reasons when reasoning about social justice, is precisely what is neglected in Condorcet's analysis. Condorcet's particular conception of the vote as a quest for truth - that is, as a public reasoning process which necessary leads to the recognition of the anteriority and priority of the equality of natural rights - makes no room for the idea of plural impartial reasons and does not escape, from that point of view, what Sen identifies as a main weakness of the transcendental tradition.

Finally, with his conception of the nature of the public decision-making process, Condorcet is faced with a paradox he will resolve through public instruction. Political constitutions and laws are consequences of natural rights and must hence guarantee their 
preservation. Jointly, the principle of the equality of natural rights requires that all men enjoy the right of political participation. But, without enlightened citizens - that is, without the implementation of an ambitious system of public instruction spreading reason and knowledge - popular sovereignty leads to tyranny and injustice. Hence democratic public decisions, in Condorcet's view, crucially depend on the prior establishment of just social institutions, and the conception of justice as grounded on equal liberty provides him with the guidelines to lay the foundations of that central social institution (Le Chapelain 2010). Assimilating Condorcet to CT leads, in our opinion, to an unfair minimization of the role of institutions in his overall reflections on the process of public decision-making, and to a downplaying of his concern with defining what just institutions would be.

\section{Sen's metaranking as a way to reconcile both traditions}

We stressed in the two preceding sections that neither Rawls nor Condorcet properly belongs to the traditions defined by Sen in The Idea of Justice, and that this is because of their appeal to the concept of "public reason" - for Rawls - or "collective reason" - for Condorcet - which are closely connected to the emergence of a notion of the "reasonable" as a result of a public deliberative dialogue. In this section, we pursue the same line of analysis with respect to the work of Sen himself. In section 3.1, we show that the "early" Sen defines a concept which appears to be capable of giving an account of the way a notion of the "reasonable" may emerge in society: this is the concept of metaranking, through appeal to which he resolves his famous liberal paradox. We argue that this concept enables us to forge a link between the transcendental and the comparative traditions. In section 3.2, we attempt to show that many passages of Sen's The Idea of Justice echo the concept of metaranking, and thus that Sen's last book does not exclusively belong to the comparative tradition.

\subsection{The "early" Sen: the liberal paradox and the metaranking of preferences}

The deliberative process necessarily implies the modification of individual preferences and values. By appeal to the concept of metaranking, which takes this issue into account, we are able to show that TT and CT are not, in fact, logically distinct theoretical approaches and, more precisely, that there is a continuum of positions between CT and TT. Strikingly, the concept that enables us to tackle this issue was developed by Sen himself, partially in order to resolve his famous paradox of the Paretian liberal. Let us now remind ourselves of this impossibility result and the related concept of metaranking.

In 1970, Sen introduced individual liberties and rights into the framework of social choice theory via a condition of liberalism and the notion of decisiveness: individuals must be decisive - their preferences must be acknowledged by society - over some pairs of social states which belong to their private sphere. Sen shows that this condition of liberalism 
coupled with a weak Pareto principle leads to the impossibility of social choice: this is the impossibility of the Paretian liberal. Sen provides a famous example in order to illustrate the paradox: whether or not to read to read Lady Chatterley's Lover, the book by D. H. Lawrence which was the subject of a 1960 obscenity trial in the UK.

Let a society comprise two individuals: A who is a prude and B who is lewd. Three social states are available: $(a)$ individual A reads the book, $(b)$ individual B reads it, or $(c)$ nobody reads it. A, who is a prude, wants to protect individual B from perverse texts, and so prefers $c$ to $a$ and $a$ to $b$. B, who is lewd and prefers that A be shocked rather than the should read the book himself, prefers $a$ to $b$ and $b$ to $c$. As a consequence, according to the weak Pareto principle (which states that any unanimous preference must be acknowledged by society as a whole) we must prefer $a$ to $b$, since A and B (the totality of society in this example) share this preference. Further, since social states $a$ (respectively $b$ ) and $c$ only differ in that individual A (respectively B) reads the book, $a$ (respectively $b$ ) and $c$ must belong to the private sphere of individual A (respectively B), and so society must prefer $c$ to $a$ (respectively $b$ to $c$ ). Thus $a$ is preferred to $b, b$ to $c$, and $c$ to $a$.

Sen (1976) goes on to propose a solution to his paradox. He begins by reiterating that it is obvious that weakening the condition of liberalism and thus choosing social state $a$ is not the best solution, since it leads to the selection of personal features that both individuals dislike. Social state $b$, which respects individual rights, seems therefore preferable, except that it conflicts with the weak Pareto principle; weakening this principle is hard to justify, for it represents the preference for unanimity. Sen thus proceeds carefully: according to him (for individual $i$ ), there is a distinction between $i$ preferring $x$ to $y$, and $i$ wanting his/her preference to count in determining the outcome of the social decision-making process, particularly if this preference is not exclusively individual $i$ 's concern. But Sen does not stop here. If individual A does not wish, for instance, that her preference for $c$ over $b$ should count at the collective level, she still continues to prefer $c$ to $a$ and $a$ to $b$. Then, because of the transitivity of individual preferences, the conflict still occurs. Sen notes that: "extending this reasoning, I may decide, for the sake of consistency, not to insist that my preferences be taken into account even in choices over some pairs that are not exclusively your concern" (Sen 1976, p. 236, emphasis added). That is to say that, for the sake of consistency, A also renounces her preference for $a$ over $b$. According to Sen's solution, the social state finally chosen will thus be $b$.

But Sen himself criticizes the drawbacks of a systematic weakening of one or the other conditions invoked in the paradox: "to discuss whether a person's preference should count or not we may need to know more than what the preferences happen to be, e.g. the reasons for holding these preferences" (Sen 1976, p. 237). Only an examination of the motivations and values of a person enables one to determine which solution should be proposed. In "Choice, Orderings and Morality" (1974) and "Rational Fools" (1977), he thus proposes to use the 
concept of metaranking - the "ordering of the preference orderings" - to cope with the liberal paradox. Let us develop Sen's ideas as related to this proposal. ${ }^{3}$

In "Rational Fools," Sen strongly criticizes the neo-classical theory according to which an individual will have only one preference ordering - one which "is supposed to reflect his interests, represent his welfare, summarize his idea of what should be done, and describe his actual choices and behavior" (Sen 1977, p. 99). Sen proposes another structure to tackle this issue: a ranking of rankings of preferences - that is, a metaranking of preferences. The proposal is that an individual can rank her rankings of preferences according to some moral consideration pertaining to what "the person concerned would have morally preferred" (Sen notes that the ranking need not necessarily be complete, "as indeed a moral view need not be"; Sen 1974, p. 62). The appeal to metarankings makes it possible to solve both the Prisoner's Dilemma and Sen's liberal paradox, by invoking two distinct notions of morality. For the Prisoner's Dilemma, Pareto Optimality is favored: "social inoptimality might be avoidable only by a moral code of behavior that drives a wedge between preferences and welfare" (Sen 1974, p. 62, emphasis added). In the present case, this moral code of behavior means that individuals renounce the option to play rationally (i.e., to confess) in order to reach a Pareto-optimal social state: "sacrificing some individual gain for the sake of a rule of good behavior by all which ultimately makes everyone better off is indeed one of the most talkedof aspects of morality" (Sen 1974, p. 59, emphasis added). In terms of metaranking, if an individual wants to follow this moral code, she will choose a preference ordering which is ranked higher in her metaranking. ${ }^{4}$ On the contrary, for the resolution of the liberal paradox, Sen claims that morality in this case requires weakening the Pareto condition and respecting individual rights. One can obtain this kind of result if individuals are "liberal enough": "And I am liberal enough to believe that if he does not want to then he should not. So given his preference, I should not really prefer that he should read the book" (Sen 1974, p. 65). Again, this kind of reasoning can be taken into account thanks to the appeal to metarankings. And Sen then concludes that the difference between both situations does not lie in the ordering of preferences but "in the ordering of the preferences ordering" (Sen 1974, p. 66).

However, Sen's plea that we take into account individual motivations and values via the concept of metaranking stands in need of closer examination: how can we understand the fact that individuals are able to elaborate their metaranking at all? Under what conditions does such an elaboration become possible? Although Sen does not expand on this point, certain terms that he uses are highly suggestive: individuals agree to abandon a part of their preferences "for the sake of consistency," "for the sake of a rule of good behavior by all," or in order to respect "a moral code of behavior." All the terms listed above ("rule," "by all," "moral code") seem to point to the fact that introspection is not a sufficient basis on which

\footnotetext{
${ }^{3}$ For a quick survey of the issue of metaranking, see for instance Ege and Igersheim 2011, pp. 4-6.

${ }^{4}$ Notably, in this passage Sen refers to Kant's moral law in order to stress that "non-confessing" satisfies it.
} 
individuals may elaborate their metaranking. We may indeed wonder whether an individual would agree to observe a moral code of behavior if she were the only person to do so. In the specific context of social choice, is it credible that there should be respect for a given moral code of behavior without any deliberation, without any public dialogue or, in a word, without the other members of society? For instance, with his concept of "laundering preferences," Goodin stresses that in a given social context individuals will be ready to correct their preferences by themselves: "they will express only their public-oriented, ethical preferences, while suppressing their private-oriented, egoistic ones" (Goodin 1986, p. 88). Strikingly, this brings us back to Sen's 1976 resolution of the liberal paradox in which he maintains that there is a difference between an individual preferring one social state to another and an individual wanting that her preference be taken into account in the process of social choice.

We thus claim that the emergence of a moral code of behavior (or, as we may prefer to say, a common basis of values, the reasonable, public reason, etc.) plainly presupposes the existence of a deliberative process. Consequently, Sen's resolution of the impossibility of the Paretian liberal and the subsequent appeal to the concept of metaranking presuppose the existence of a public deliberative process and the emergence of a common basis of values which stems from it. This is the condition of possibility of the elaboration of an individual metaranking. ${ }^{5}$ Therefore, the concept of metaranking can be seen as a way to reconcile the transcendental and the comparative approaches, since it simultaneously stems from and gives rise to the reasonable.

\subsection{Sen's Idea of Justice: not only comparative}

Although the "later" Sen no longer mentions the concept of metaranking, it is implicit in many passages of his Idea of Justice. Although, for Sen, this deliberative process is not explicitly associated with the "quest for truth" in the manner of Condorcet, or with the choice of a set of principles of justice in the manner of Rawls, it unquestionably allows the formation of a set of reasonable values according to which individuals will be able to rank and compare social states. Let us consider, for instance, the fundamental role which Sen assigns to the freedom of the press: "one of the central issues to consider for the advancement of public reasoning in the world is support for a free and independent press" (Sen 2009, p. 335). He explicitly asserts that freedom of the press enhances public deliberation and hence the formation of reasonable and common values:

informed and unregimented formation of values requires openness of communication and argument. The freedom of the press is crucial to this process. Indeed, reasoned value formation is an interactive process, and the press has a major role in making these interactions possible. New standards and priorities (such as the norm of smaller families with less frequent child

\footnotetext{
${ }^{5}$ Note, however, that this elaboration does not necessarily imply that there is a unique way of reconstructing individual preferences, nor will it to a complete ordering of orderings.
} 
bearing, or greater recognition of the need for gender equity) emerge through public discourse, and it is public discussion, again, that spreads the new norms across different regions. (Sen 2009, p. 336).

This extract sheds light on Sen's very specific conception of public deliberation: it must favor the emergence of new social norms and priorities. A close link between the latter and the concept of metaranking is not hard to find: according to the new norms and priorities brought about by public deliberation, individuals are able to construct their own metaranking, i.e., to modify their individual preferences according to the reasonable values which stem from public discourse.

As well as this, Sen makes special reference to the liberal paradox, seen as stressing the importance of a specific kind of individual preference: "one of the lessons drawn from the social choice result of 'the impossibility of the Paretian liberal' ... is the crucial relevance of mutually tolerant preferences and choice" (Sen 2009, p. 337). But is it plausible to consider as Sen indeed seems to pretend - that the emergence of such tolerant preferences has nothing in common with a more transcendental tradition; or that the development of a reasonable set of values held in common by all - such as liberal values - has no connection at all with transcendental points of view according to which one should respect individual rights and freedoms? Of course, such a position is difficult to maintain. Rather, one should acknowledge, with Valentini (2011, p. 311-312) that Sen's

ideal of public and open reasoning about justice either is so inclusive as to become almost empty (given that public reasoning will contain completely irreconcilable views) or it surreptitiously implies certain substantive moral commitments which automatically exclude perspectives that are distant enough from the liberal one. The latter alternative is probably most likely to be correct .... Certain fundamental commitments - such as commitments to liberty and equality - must be non-negotiable. To the extent that Sen does not wish to abandon those commitments, his view cannot boast much greater inclusiveness that Rawls's.

This long quotation clearly shows that the logical implications of the existence of a "good" or "fair" process of public reasoning cannot be ignored: such a process of reasoning both stems from and conveys values with transcendental characteristics.

\section{Concluding remarks}

In this paper, we questioned Sen's dichotomy between transcendental and comparative approaches, showing that Condorcet, Rawls, and Sen himself do not belong exclusively to the tradition within which Sen locates them. We stressed that this is due to their appeal to the concept of the "reasonable" and the significance they assign to the public deliberative process. 
For all three authors, these two notions coexist as a result of a two-way mechanism: first, the reasonable (i.e., the fact that members of a society are reasonable beings) is the condition of possibility which permits the existence of "fair" or "good" public discussion; second, this process of public discussion leads to the emergence of the reasonable in a society, and/or to its reinforcement.

Further, to return to the metaphor with which we began the paper, we claimed that the concept of metaranking, which involves the idea of modifying individual preferences, forms a bridge between the transcendental and the comparative traditions. To pursue the metaphor, none of the authors under consideration are on the transcendental or the comparative banks; all of them are somewhere on the bridge; yet at different points along it. One can allow that Rawls and Condorcet are closer to the transcendental bank, since their theories tend to propose a complete ranking of social states; but while this is not Sen's purpose, one must nevertheless acknowledge that some transcendental - or reasonable - basis is necessary to allow the emergence of any collective ranking, complete or not. We have thus demonstrated that, whether explicitly or implicitly, Condorcet, Rawls, and Sen share this point of view.

\section{References}

Arrow K. J., 1951, Social choice and individual values, 1st ed., New York, Wiley.

Baker K. M., 1975, Condorcet. From natural philosophy to social mathematics, Chicago, University of Chicago Press.

Black D., 1958, The theory of committees and elections, Cambridge University Press.

Bru B. and Crépel P., 1994, Condorcet. Arithmétique politique. Textes rares ou inédits (17671789), Paris, INED.

Condorcet, 1785, Essai sur l'application de l'analyse à la probabilité des décisions rendues à la pluralité des voix, Paris, Imprimerie royale. Translation: An essay on the application of probability theory to plurality decision-making, in Condorcet-Foundations of Social Choice and Political Theory, I. McLean and F. Hewitt (eds. and trans.), 1994, Edward Elgar.

Condorcet,1787, Lettres d'un bourgeois de New-Haven à un citoyen de Virginie, in F. Arago et A. O'Connor, éd., Euvres de Condorcet (OC), Paris, Firmin Didot, 1847-1849, t.IX, pp. 193.

Condorcet (1792), De la nature des pouvoirs politiques dans une nation libre, in F. Arago et A. O’Connor, éd., OC, Paris, Firmin Didot, 1847-1849, t. X, pp. 587-613.

Ege, R. et Igersheim, H., 2010, "Rawls's theory of justice and its relations to the concept of 'merit goods'", The European Journal of the History of EconomicThought17, 1001-1030.

Ege, R. and Igersheim, H., 2011, "Introduction and Overview" in Ege, R. and Igersheim, H. (eds.), Freedom and Happiness in Economic Thought and Philosophy, London: Routledge, 2011, pp. 1-12. 
Faccarello G., 1990, "Le legs de Turgot : aspects de l'économie politique sensualiste de Condorcet à Roederer," in G. Faccarello and P. Steiner, eds., La pensée économique pendant la RévolutionFrançaise, P. U. G., 1990, pp. 67-107.

Faccarello G., 1992, "Turgot et l'économie politique sensualiste," in A. Béraud and G. Faccarello, eds.,Nouvelle Histoire de la pensée économique, Tome 1, Des scolastiques aux classiques, Paris, Editions La découverte, pp. 254-288.

Gamel, C., 2010, "Que faire de l'approche par les capacités? Pour une lecture rawlsienne de l'apport de Sen", Working paper GREQAM n²010-30.

Goodin R. E., 1986, "Laundering preferences," in J. Elsteret A. Hylland (eds), Foundations of social choice theory, Cambridge, Cambridge University Press, pp. 75-101.

Grofman B. and Feld S.L, 1988, "Rousseau's general will: A condorcetian perspective," American Political Science Review 82, pp. 567-576.

Guilbaud G. T., 1952, "Les théorie de l'intérêt général et le problème logique de l'agrégation," Economie appliquée, 5, n 4, pp. 501-584.

Kandil, F., 2010, "Idéale ou comparative :Quelle approche pour la justice sociale ?", Revue Economique 61, 213-236.

Le Chapelain C. (2010), "L'instruction publique de Condorcet. Progrès économique et réflexions sur la notion de capital humain," Revue Economique, 61(2), pp. 281-298.

Rawls, J., 1971, A Theory of Justice, Oxford University Press.

Rawls, J., 1985, "Justice as Fairness : Political, not Metaphysical", Philosophy and Public Affairs 14, 223-251.

Rawls, J., 1993, Political Liberalism, Columbia University Press.

Rieucau J. N., 1997, Nature et diffusion du savoir dans la pensée économique de Condorcet, $\mathrm{PhD}$ Thesis, University of Paris I.

Robeyns, I, 2012, "Are transcendental theories of justice redundant?",Journal of Economic Methodology 19, 159-163.

Rousseau, J.-J., 1755, Discourse on the Origin and the Foundations of Inequality Among Men, in Rousseau, The Discourses and other early political writings, Translated by V. Gourevitch, Cambridge University Press, 1997, 113-222

Sen A. K., 1970, Collective Choice and Social Welfare, Holden Day.

Sen A. K., 1974, "Choice, Orderings and Morality," in S. Körner (ed.), Practical Reason, Oxford, Blackwell, pp. 54-67.

Sen A. K., 1976, “Liberty, Unanimity and Rights,” Economica, 43, pp. 217-245.

Sen A. K., 1977, "Rational Fools: A Critique of the Behavioural Foundations of Economic Theory," in Sen, A.K., Choice, Welfare and Measurement, Oxford, Blackwell, 1982, pp. 84106.

Sen A. K., 2006, "What do we want from a theory of justice?," The Journal of Philosophy 103 , pp. 215-238. 
Sen A. K., 2009, The Idea of Justice, Harvard University Press.

Sen A. K., 2012, "Values and Justice", Journal of Economic Methodology 19, 101-108.

Valentini L., 2011, "A paradigm shift in theorizing about justice? A critique of Sen," Economics and Philosophy 27, 297-315. 


\section{Documents de travail du BETA}

2012-01 Unanticipated vs. Anticipated Tax Reforms in a Two-Sector Open Economy Olivier CARDI, Romain RESTOUT, janvier 2012.

2012-02 University Technology Transfer: How (in-)efficient are French universities? Claudia CURI, Cinzia DARAIO, Patrick LLERENA, janvier 2012.

2012-03 L'autorité de la concurrence doit-elle, dans le cadre de sa fonction consultative disposer de toutes les libertés?

Marc DESCHAMPS, juin 2012.

2012-04 Currency devaluation with dual labor market : Which perspectives for the Euro Zone? Amélie BARBIER-GAUCHARD, Francesco DE PALMA, Giuseppe DIANA, juin 2012.

2012-05 The Routinization of Creativity: Lessons from the Case of a video-game Creative Powerhouse.

Patrick COHENDET, Patrick LLERENA, Laurent SIMON, juin 2012.

2012-06 Status-seeking and economic growth: the Barro model revisited.

Thi Kim Cuong PHAM, juin 2012.

2012-07 Considerations on partially identified regression models.

David CERQUERA, François LAISNEY, Hannes ULLRICH, juillet 2012.

2012-08 Static and Dynamic Effects of Central Bank Transparency

Meixing DAl, juillet 2012.

2012-09 La taxe Tobin : une synthèse des travaux basés sur la théorie des jeux et l'économétrie Francis BISMANS, Olivier DAMETTE, juillet 2012.

2012-10 Do husbands and wives pool their incomes? Experimental evidence.

Miriam BEBLO, Denis BENINGER, juillet 2012.

2012-11 Incitation à l'adoption de technologies propres.

Mourad AFIF, juillet 2012.

2012-12 Innovation stratégique et business model des écosystèmes " mobiquitaires ": rôle et identification de l'acteur leader.

Amel ATTOUR, août 2012.

2012-13 Motivation crowding-out: Is there a risk for science?

Julien PENIN, septembre 2012.

2012-14 Caractéristiques de la diversité au sein des conseils d'administration et performance financière : une étude empirique sur les entreprises du CAC40

Houda GHAYA, Gilles LAMBERT, septembre 2012. 

Dichotomy

Ragip EGE, Herrade IGERSHEIM, Charlotte LE CHAPELAIN, octobre 2012.

La présente liste ne comprend que les Documents de Travail publiés à partir du $1^{\mathrm{er}}$ janvier 2012. La liste complète peut être donnée sur demande.

This list contains the Working Papers written after January 2012, 1rst. The complet list is available upon request. 